\title{
Formulation and evaluation of pumpkin fruit (Cucurbita maxima L.) emulgel
}

\section{Formulasi dan evaluasi sediaan emulgel daging buah labu kuning (Cucurbita maxima L.)}

\author{
Agitya Resti Erwiyani ${ }^{*}$, Sri Mustika Ayu ${ }^{1}$, Winda Ayu Ningtyas ${ }^{1}$, Rissa Laila Vifta ${ }^{1}$ \\ ${ }^{1}$ Program Studi Farmasi, Fakultas Kesehatan, Universitas Ngudi Waluyo \\ *Corresponding author: agityaresti@gmail.com
}

\begin{abstract}
Background: The fruit of pumpkin (Cucurbita maxima D.), one of genus Cucurbita, family Cucurbitaceae, has antioxidant activity due to the content of metabolites including amino acids, fatty acids, $\alpha$-tocopherol, $\beta$ tocopherol, $\beta$-carotene, $\beta$-cryptoxanthin, and $\beta$-sitosterol. The content of carotenoids and tocopherols in pumpkin has antioxidant activity, reduces skin damage due to sun exposure, and can slow down the aging process.

Objective: The study aimed to formulate pumpkin fruit emulgel and evaluate its physical stability during storage

Method: Emulgel contains pumpkin fruit extracts at a concentration of $0,5-1,5 \% \mathrm{w} / \mathrm{v}$. Emulgel evaluations were organoleptic, homogeneity, $\mathrm{pH}$, spreadability, adhesion, and viscosity at $2-8^{\circ} \mathrm{C}$, room temperature, and $40^{\circ} \mathrm{C}$. The stability test observed the physical properties for 28 days.

Results: Pumpkin fruit extracts contain flavonoids based on the TLC test. Emulgel showed organoleptic yellow color with $\mathrm{pH}$ in the range of 5, homogeneous, adhesion for more than 1 second, dispersion $5-7 \mathrm{~cm}$, and viscosity $2000-4000$ cP. Storage for 28 days did not show a significant difference at all storage temperatures and centrifugation tests.
\end{abstract}

Conclusion Pumpkin fruit emulgel is stable at all storage temperatures $2-8{ }^{\circ} \mathrm{C}, 28 \pm 2{ }^{\circ} \mathrm{C}$, and $40 \pm 2{ }^{\circ} \mathrm{C}$.

Keywords: emulgel, pumpkin, formulation, physical stability

\section{Intisari}

Latar belakang: Buah labu kuning (C. maxima D.) yang termasuk dalam genus Cucurbita famili Cucurbitaceae memiliki aktivitas antioksidan karena kandungan metabolit diantaranya asam amino, asam lemak, $\alpha$ tokoferol, $\beta$-tokoferol, $\beta$-karoten, $\beta$-kriptoxantin, dan $\beta$-sitosterol. Kandungan karotenoid dan tokoferol dalam labu kuning memiliki aktivitas antioksidan, menurunkan kerusakan kulit akibat paparan sinar matahari serta dapat memperlambat penuaan dini.

Tujuan: Tujuan penelitian untuk memformulasikan emulgel daging buah labu kuning serta evaluasi stabilitas fisik selama penyimpanan

Metode: Emulgel mengandung ekstrak daging buah labu kuning pada konsentrasi 0,5 - 1,5 \% b/v. Evaluasi emulgel meliputi organoleptis, homogentitas, $\mathrm{pH}$, daya sebar, daya lekat, dan viskositas pada $2-8^{\circ} \mathrm{C}$, suhu kamar dan $40^{\circ} \mathrm{C}$. Uji stabilitas dilakukan dengan pengamatan sifat fisik selama 28 hari.

Hasil: Ekstrak daging buah labu kuning mengandung flavonoid berdasarkan uji KLT. Emulgel menunjukkan organoleptis berwarna kuning dengan $\mathrm{pH}$ berkisar 5, homogen, daya lekat lebih dari 1 detik, daya sebar 5 - 7 $\mathrm{cm}$, dan viskositas 2000 - $4000 \mathrm{cP}$. Penyimpanan selama 28 hari tidak menunjukkan perbedaan yang signifikan pada semua suhu penyimpanan dan uji sentrifugasi.

Kesimpulan: Emulgel daging buah labu kuning stabil pada semua suhu penyimpanan yaitu $2-8{ }^{\circ} \mathrm{C}, 28 \pm 2{ }^{\circ} \mathrm{C}$ dan $40 \pm 2{ }^{\circ} \mathrm{C}$.

Kata kunci : emulgel, labu kuning, formulasi, stabilitas fisik 


\section{Pendahuluan}

Labu kuning (C. maxima L.) merupakan tanaman yang termasuk dalam keluarga Cucurbitaceae yang banyak dimanfaatkan menjadi produk olahan makanan. Labu kuning memiliki kandungan fenolik, tanin, saponin, flavonoid, vitamin C, vitamin A, karbohidrat, protein, serta prekursor Vitamin A yang memiliki banyak manfaat seperti karotenoid dan $\beta$-karoten (Muchirah et al., 2018; Nakhon et al., 2017). Pemanfaatan labu kuning telah banyak dilakukan karena mengandung sumber nutrisi baik, memperbaiki masalah pencernaan, dan memiliki peluang tinggi untuk dapat dimanfaatkan sebagai sediaan kosmetik (Indrianingsih et al., 2019).

Labu kuning dilaporkan memiliki manfaat bagi kesehatan salah satunya aktivitas antioksidan karena kandungan antioksidan alami. Daging buah labu kuning mengandung metabolit sekunder yang lebih bervariasi dibandingkan bagian biji. Ekstrak etanol daging labu kuning mengandung fenol 0,277 $\pm 0,004 \mathrm{~g} / 100 \mathrm{~g}$, flavonoid 0,246 $\pm 0,013 \mathrm{~g} / 100 \mathrm{~g}$, tannin 0,01 $\pm 0,006$ $\mathrm{g} / 100 \mathrm{~g}$, alkaloid 0,0638 $\pm 0,004 \mathrm{~g} / 100 \mathrm{~g}$ dan positif mengandung saponin. Labu kuning pada konsentrasi 10,0 mg/ml menghasilkan aktivitas antioksidan dengan persentase penghambatan sebesar 39,0 $\pm 0,301 \%$ sehingga labu kuning dapat dijadikan sebagai sumber antioksidan yang baik (Muchirah et al., 2018). Labu kuning perlu dimanfaatkan menjadi bentuk sediaan kosmetik untuk meningkatkan potensinya. Salah satu bentuk sediaan kosmetik yang dapat dibuat adalah sediaan emulgel.

Emulgel merupakan suatu sistem emulsi dengan penambahan gelling agent. Emulsi dapat ditambahkan obat atau bahan aktif yang dilepaskan perlahan dari fase internal menuju ke fase eksternal dan diabsorbsi dengan system pelepasan terkontrol di kulit. Emulgel memiliki karakteristik yang baik seperti mudah diaplikasikan, mudah dicuci, lembut digunakan, kompatibel dengan berbagai eksipien dan dapat larut dalam air (Khan et al., 2020). Pembuatan ekstrak daging buah labu kuning dalam bentuk sediaan emulgel belum pernah dilakukan. Penelitian ini bertujuan untuk memformulasi daging buah labu kuning dalam bentuk sediaan emulgel dan dilakukan evaluasi karakteristik fisik selama 4 minggu pada suhu dingin $\left(2-8{ }^{\circ} \mathrm{C}\right)$, suhu ruang $\left(28 \pm 2{ }^{\circ} \mathrm{C}\right)$ dan suhu tinggi $\left(40 \pm 2{ }^{\circ} \mathrm{C}\right)$.

\section{Metode}

\subsection{Alat dan bahan}

Alat yang digunakan dalam penelitian antara lain neraca analitik (Ohauss), alat gelas (Pyrex), waterbath (DHH-88), rotary evaporator (Biobase), oven (Memmert), blender (Philips), 
ayakan 40 mesh, viskometer (Brookfield DV2T), pH meter (Ohaus Starter 300), jangka sorong (Mitutoyo), uji daya lekat, seperangkat alat uji daya sebar, mortar dan stamper.

Bahan yang digunakan dalam penelitian antara lain labu kuning yang diperoleh dari Getasan, Kabupaten Semarang, Jawa Tengah, span 60 (Brataco, kualitas farmasetis), tween 60 (Brataco, kualitas farmasetis), karbomer 940 (Brataco, kualitas farmasetis), minyak zaitun (Brataco, kualitas farmasetis), setil alcohol (Brataco, kualitas farmasetis), trietanolamin (Brataco, kualitas farmasetis), propilen glikol (Brataco, kualitas farmasetis), akuades, metil paraben (Merck), propil paraben (Merck). Bahan untuk identifikasi Kromatografi Lapis Tipis (KLT) antara lain fase diam silica gel GF 254, fase gerak n-butanol: asam asetat: air (3: 1: 1).

\subsection{Ekstraksi daging buah labu kuning}

Metode maserasi dipilih untuk melakukan ekstraksi daging buah labu kuning dengan etanol 96\% (1: 10). Serbuk daging buah labu kuning ditimbang sebanyak $500 \mathrm{~g}$ dan dilakukan maserasi menggunakan 3,75 L etanol 96\% selama 3 x 24 jam. Setelah itu, maserat dipisahkan dari ampas dan dilakukan remaserasi dengan 1,25 L etanol 96\% selama 2 x 24 jam. Maserat 1 dan 2 dikumpulkan dan diuapkan menggunakan rotary evaporator dilanjutkan dengan pemanasan di atas waterbath hingga didapatkan ekstrak kental. Ekstrak yang diperoleh dilakukan perhitungan rendemen ekstrak.

\subsection{Identifikasi kandungan senyawa menggunakan KLT}

Identifikasi kandungan metabolit dilakukan menyiapkan fase diam silika gel GF 254 yang diaktifkan sebelum digunakan dengan oven suhu $105^{\circ} \mathrm{C}$ selama 30 menit. Fase gerak yaitu nbutanol: asam asetat: air (3: 1: 1) dan deteksi dengan penampak bercak uap ammonia. Ekstrak diambil sebanyak $50 \mathrm{mg}$ dan dilarutkan dalam pelarut selanjutnya dilakukan elusi hingga batas atas penandaan. Noda yang terbentuk dilakukan pengamatan pada sinar tampak, UV 254 dan UV 366 nm (Mulangsri \& Zulfa, 2020).

\subsection{Formulasi emulgel daging buah labu kuning}

Pembuatan emulsi primer (m/a) dimulai dengan menyiapkan fase minyak dan fase air. Fase minyak dibuat dengan mencampurkan span 60 dan BHT ke dalam minyak zaitun. Fase air dibuat dengan mencampurkan ekstrak etanol daging buah labu kuning, tween 50, metal paraben dan propil paraben yang sebelumnya dilarutkan dalam propilen glikol. Campuran fase air dimasukkan ke dalam akuades dan dilakukan pengadukan hingga homogen. Selanjutnya, masing-masing fase minyak dan fase air dipanaskan di atas waterbath suhu $70^{\circ} \mathrm{C}$. Fase minyak ditambahkan sedikit demi sedikit pada fase air dan dilakukan pengadukan hingga suhu ruang dan menghasilkan emulsi yang homogen. Gel dibuat dengan menyiapkan karbomer 940 yang didispersikan ke dalam akuades 
selama 24 jam. Gel yang terbentuk ditambahkan trietanolamin untuk meningkatkan pH gel, dilakukan pengadukan hingga homogen. Emulsi m/a didispersikan ke dalam basis gel hingga terbentuk emulgel (Jufri et al., 2018).

Tabel 1. Formula emulgel daging buah labu kuning

\begin{tabular}{lccc}
\hline \multicolumn{1}{c}{ Bahan } & Basis (\%) & Formula 1 (\%) & Formula 2 (\%) \\
\hline Ekstrak etanol daging labu kuning & 0,00 & 0,50 & 1,50 \\
Karbomer 940 & 2,00 & 2,00 & 2,00 \\
Minyak zaitun & 5,00 & 5,00 & 5,00 \\
Span 60 & 1,13 & 1,13 & 1,13 \\
Tween 60 & 3,87 & 3,87 & 3,87 \\
Propilen glikol & 10,00 & 10,00 & 10,00 \\
BHT & 0,01 & 0,01 & 0,01 \\
Metil paraben & 0,18 & 0,18 & 0,18 \\
Propil paraben & 0,02 & 0,02 & 0,02 \\
Trietanolamin & 3,00 & 3,00 & 3,00 \\
Akuades & ad 100 & ad 100 & ad 100 \\
\hline
\end{tabular}

\subsection{Evaluasi sifat fisik emulgel daging buah labu kuning}

Karakteristik fisik sediaan emulgel daging buah labu kuning dilakukan evaluasi dengan parameter organoleptis, uji pH, viskositas, daya lekat dan daya sebar selama 28 hari. Sediaan emulgel disimpan pada 3 variasi suhu yang berbeda untuk mengevaluasi stabilitas emulgel yaitu 2 $8{ }^{\circ} \mathrm{C}, 28 \pm 2{ }^{\circ} \mathrm{C}$ dan $40 \pm 2{ }^{\circ} \mathrm{C}$ dengan pengamatan organoleptis, $\mathrm{pH}$, viskositas, daya lekat dan daya sebar setiap minggu. Uji mekanik emulgel dilakukan dengan sentrifugasi untuk mengamati stabilitas emulgel.

\subsubsection{Pengamatan organoleptis dan uji $\mathrm{pH}$}

Warna, bau dan tekstur sediaan emulgel diamati dan dicatat sebagai data organoleptis (Erwiyani et al., 2017). Uji pH dilakukan dengan 1,0 gram emulgel yang dilarutkan dalam akuades $100 \mathrm{~mL}$, kemudian dilakukan pembacaan pH dengan pH meter yang telah dikalibrasi menggunakan larutan standar. Pengukuran ini dilakukan 3 kali dan dinyatakan sebagai rata - rata pH (Baibhav et al., 2012).

\subsubsection{Pengukuran viskositas}

Sejumlah 50 g emoulgel diukur viskositasnya dengan viskometer Brookfield ukuran spindle No. 64 pada kecepatan putaran 100 rpm selama 1 menit. Viskositas ditunjukkan oleh angka yang tertera pada jarum merah pada skala.

\subsubsection{Uji daya lekat}

Sejumlah 0,5 g emulgel diletakkan pada bagian tengah kedua objek gelas dengan beban $1 \mathrm{~kg}$ selama 5 menit. Kedua ujung objek dikaitkan pada alat. Daya lekat dihitung sebagai waktu yang diperlukan untuk kedua objek gelas terlepas. 


\subsubsection{Uji daya sebar}

Sejumlah 0,5 g emulgel ditempatkan di tengah kaca yang berbentuk bulat, kemudian ditutup kaca dan diberi beban 50 g yang dinaikkan secara bertahap hingga 200 g. Diameter daya sebar diukur setelah diberi beban yang dibiarkan selama 1 menit dengan mengamati diameter pada beberapa sisi (Zulkarya \& Hastuti, 2018).

\subsubsection{Uji sentrifugasi}

Pengujian sentrifugasi dilakukan dengan memasukkan emulgel ke dalam tabung berskala dan diakukan putaran pada kecepatan $3800 \mathrm{rpm}$ menggunakan ketinggian sediaan $10 \mathrm{~cm}$ selama 5 jam. Sediaan yang stabil setelah dilakukan uji sentrifugasi menunjukkan ekivalen terhadap efek gravitasi dan kurang lebih selama satu tahun (Jufri et al., 2018).

\subsection{Analisis statistik}

Perbedaan stabilitas sediaan yang disimpan pada suhu yang berbeda dibandingkan dengan uji paired-sample T test. Hasil dinyatakan berbeda signifikan jika nilai $\mathrm{p}<0,05$.

\section{Hasil dan pembahasan}

\subsection{Ekstraksi daging buah labu kuning}

Daging buah labu kuning yang diekstraksi dengan metode maserasi menghasilkan rendemen $28,78 \%$ b/b dengan karakteristik ekstrak berwarna coklat kehitaman, berbentuk kental dan bau khas yang manis. Rendemen yang didapatkan lebih dari 10\% yang menunjukkan telah memenuhi persyaratan (Sunnah et al., 2019) dan menunjukkan bahwa ekstraksi dengan etanol 96\% efektif menarik metabolit sekunder dari labu kuning.

\subsection{Identifikasi kandungan senyawa menggunakan KLT}

Hasil identifikasi kandungan metabolit sekunder pada ekstrak buah labu kuning menunjukkan positif flavonoid (Gambar 1).
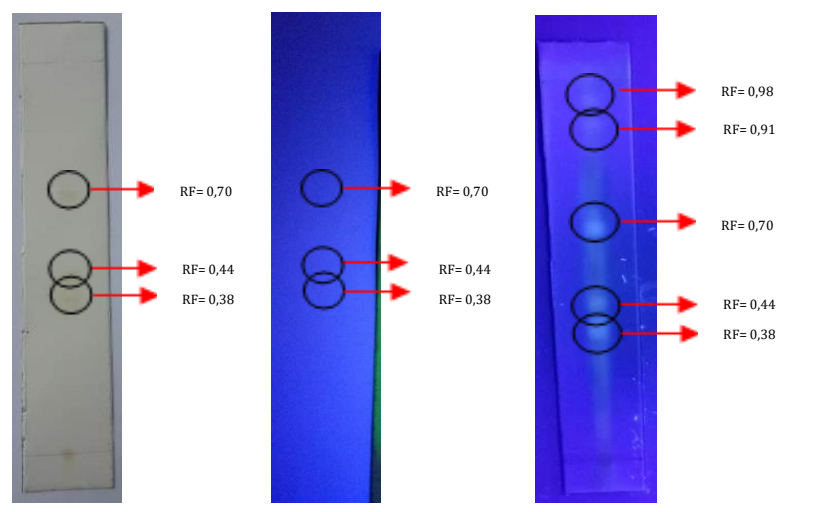

Gambar 1. Identifikasi senyawa flavonoid ekstrak etanol daging buah labu kuning menggunakan sinar tampak (a), sinar UV $254 \mathrm{~nm}$ (b) dan sinar UV $366 \mathrm{~nm}$ (c) 
Menurut Harborne (1996), senyawa flavonoid memiliki Rf pada rentang 0,28 - 0,83. Hasil KLT terlihat noda warna kuning kecoklatan yang terlihat setelah diuapkan dengan amoniak dan berfluoresensi biru pada sinar UV 366.

\subsection{Evaluasi sifat fisik emulgel daging buah labu kuning}

Evaluasi sediaan emulgel perlu dilakukan untuk mengatahui pengaruh penyimpanan terhadap karakteristik sediaan emulgel. Pengujian parameter emulgel yang dilakukan yaitu organoleptis (warna, bau dan tekstur), pH, daya sebar, daya lekat dan viskositas. Pengukuran stabilitas sediaan dilakukan dengan mengamati karakteristik setiap minggu dan dibandingkan dengan minggu 0, serta dilakukan uji sentrifugasi untuk melihat pengaruh efek gravitasi sediaan emulgel.

Pengamatan organoleptis emulgel ekstrak menunjukkan sediaan berwarna kuning muda hingga kuning kecoklatan sesuai penambahan ekstrak ke dalam formulasi, sedangkan pada basis terlihat berwarna putih karena tidak mengandung ekstrak. Emulgel pada basis dan emulgel ekstrak berbau minyak zaitun dan berbau labu. Karakteristik bau akan menentukan kualitas formulasi yaitu apabila terbentuk bau yang tidak menyenangkan kemungkinan adanya pertumbuhan bakteri. Bau yang menyenangkan juga mempengaruhi tingkat kesukaan konsumen (Shadab \& Shamsi, 2020). Formulasi basis dan emulgel ekstrak daging labu kuning memiliki tekstur lembut dan homogen. Tabel 2 menunjukkan karakteristik fisik emulgel pada penyimpanan suhu $28 \pm 2{ }^{\circ} \mathrm{C}$ selama 4 minggu. Emulgel tidak mengalami perubahan organoleptis dengan warna, bau dan tekstur yang stabil serta terlihat sediaan yang homogen. Sediaan yang dibuat memenuhi stabilitas sifat fisik untuk memastikan kualitas, efikasi dan keamanaan produk. Stabilitas fisik dapat menunjukkan waktu sediaan dapat digunakan pada penyimpanan suhu tertentu (Eff et al., 2019).

Tabel 2. Karakteristik fisik basis dan formula emulgel ekstrak daging labu kuning suhu $28 \pm 2{ }^{\circ} \mathrm{C}$

\begin{tabular}{lcccccccccccccccc}
\hline \multicolumn{1}{c}{ Parameter } & \multicolumn{4}{c}{ Basis } & \multicolumn{1}{c}{ Formula 1 } & \multicolumn{4}{c}{ Formula 2 } \\
\hline Organoleptis & M0 & M1 & M2 & M3 & M4 & M0 & M1 & M2 & M3 & M4 & M0 & M1 & M2 & M3 & M4 \\
\hline Warna & P & P & P & P & P & KM & KM & KM & KM & KM & KC & KC & KC & KC & KC \\
Bau & BM & BM & BM & BM & BM & BL & BL & BL & BL & BL & BL & BL & BL & BL & BL \\
Tekstur & L & L & L & L & L & L & L & L & L & L & L & L & L & L & L \\
Homogenitas & H & H & H & H & H & H & H & H & H & H & H & H & H & H & H \\
\hline
\end{tabular}

Keterangan: M0 - M1: pengamatan pada minggu ke-0 sampai dengan minggu ke-4; P : putih; KM : kuning muda; $\mathrm{KC}$ : kuning kecoklatan; BM : bau minyak zaitun; BL : bau labu; L : lembut; $\mathrm{H}$ : homogen

Pengukuran pH menunjukkan formulasi basis dan emulgel ekstrak daging labu kuning berada pada rentang yang memenuhi persyaratan $\mathrm{pH}$ yaitu berada pada rentang 4,85 - 6,30. Nilai pH emulgel harus memenuhi persyaratan karena pH rendah dapat menimbulkan iritasi, sedangkan nilai pH yang lebih tinggi dapat mengganggu flora normal kulit (Ambala \& Vemula, 2015; Jufri et al., 2018). Formulasi basis memiliki pH yang lebih rendah dibandingkan emulgel ekstrak labu kuning, 
hal ini dipengaruhi oleh kandungan ekstrak yang dapat menaikkan pH. Emulgel pada formula 2 menunjukkan nilai pH yang paling tinggi dibandingkan basis dan formula 1 karena mengandung ekstrak lebih banyak. Hal ini sesuai dengan penelitian Mamahit, Datu dan Lengkey (2019), penambahan ekstrak biji labu kuning dalam sediaan salep menghasilkan pH sekitar 6 .

Karakteristik pH pada suhu dingin, ruang dan tinggi selama penyimpanan 4 minggu menunjukkan adanya kenaikan $\mathrm{pH}$ terlihat pada formula basis, formula 1 dan 2 (Gambar 2). Perbedaan $\mathrm{pH}$ yang terjadi dianalisis menggunakan paired samples T-test menunjukkan formula yang disimpan selama 4 minggu pada suhu dingin, ruang dan tinggi diperoleh signifikansi $p>0,05$ yang artinya berbeda tidak signifikan. Penyimpanan selama 4 minggu pada suhu dingin $\left(2-8^{\circ} \mathrm{C}\right)$, suhu ruang $\left(28 \pm 2{ }^{\circ} \mathrm{C}\right)$ dan suhu tinggi $\left(40 \pm 2{ }^{\circ} \mathrm{C}\right)$ menujukkan sediaan stabil selama penyimpanan.

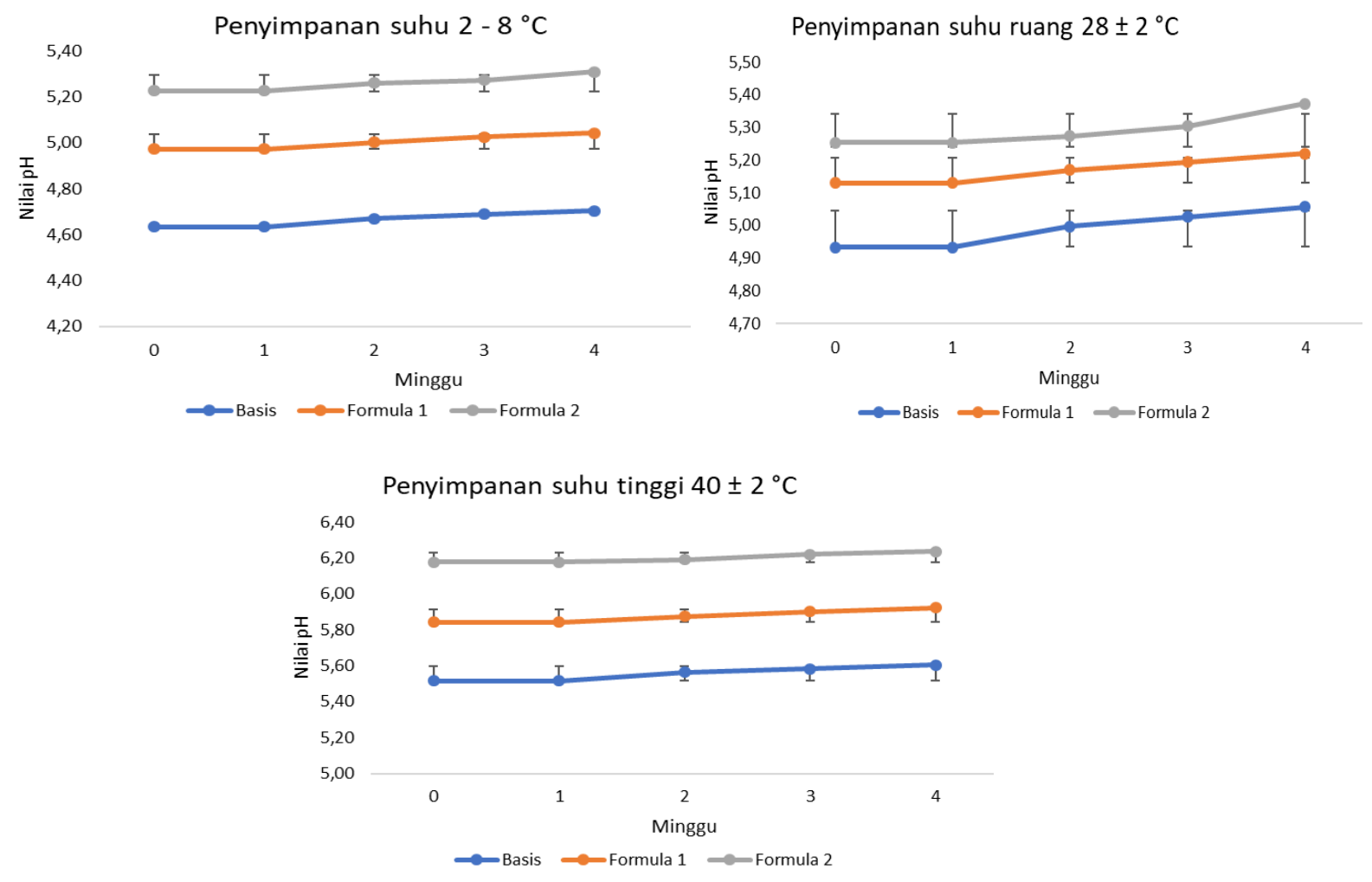

Gambar 2. Profil pH pada penyimpanan suhu dingin, ruang dan tinggi

Daya lekat basis dan emulgel daging buah labu kuning menunjukkan hasil lebih dari 1 detik. Daya lekat menunjukkan kemampuan emulgel untuk melekat (Sari et al., 2015). Kemampuan melekat emulgel dipengaruhi oleh konsentrasi gelling agent yaitu karbomer. Sifat fleksibilitas dari rantai polimer memiliki kemampuan membentuk ikatan hidrogen dan mempengaruhi tingkat pengembangan polimer sehingga kemampuan melekat formula akan terpengaruh (Varma et al., 2014). Perbedaan konsentrasi gelling agent pada formula 1 dan 2 tidak memberikan pengaruh daya 
lekat yang signifikan. Berdasarkan analisis menggunakan paired samples T-test menunjukkan tidak ada perbedaan signifikan daya lekat $(\mathrm{p}>0,05)$ pada formula basis, formula 1 dan 2 yang disimpan selama 4 minggu pada ketiga suhu penyimpanan (Gambar 3).

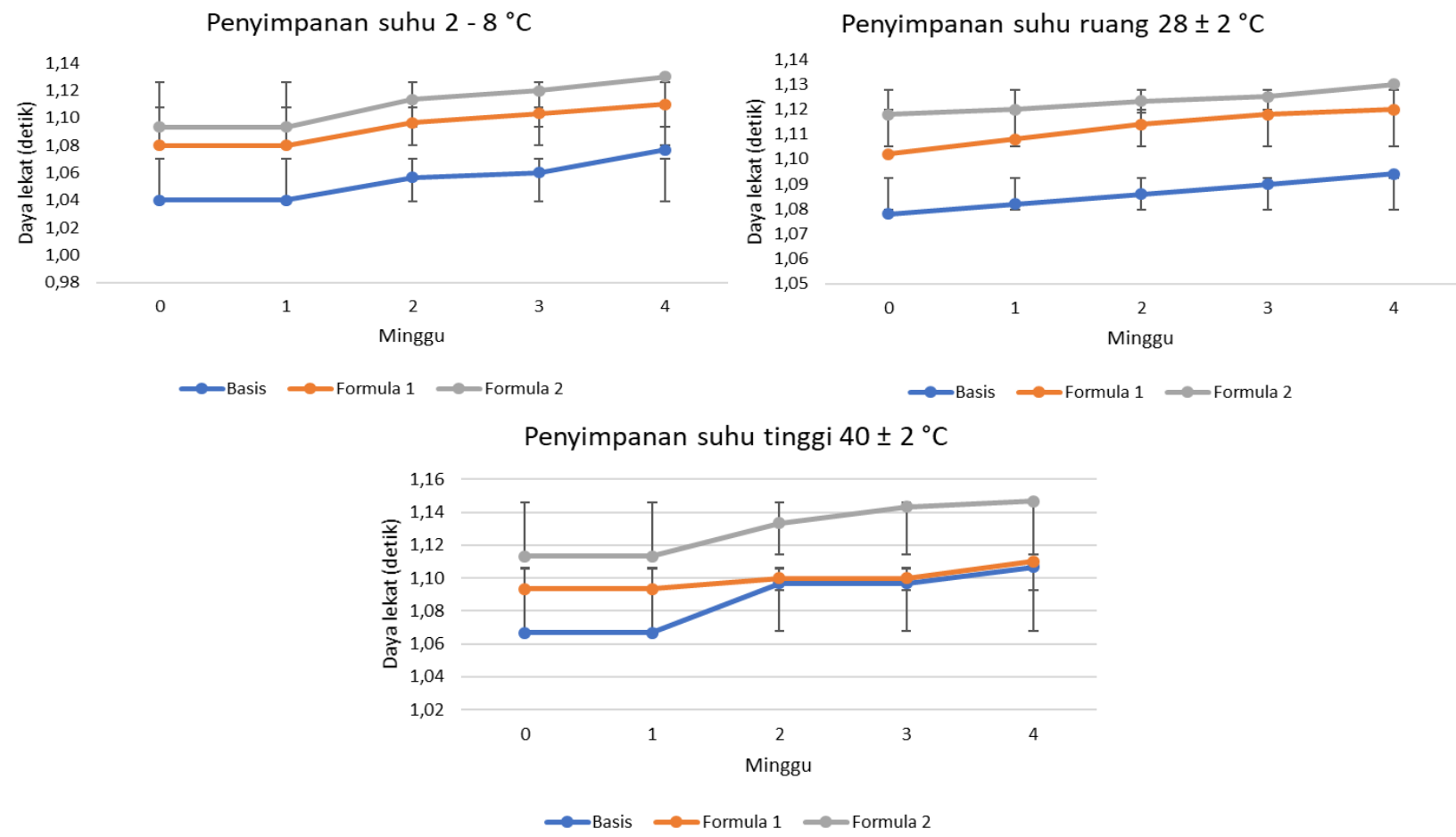

Gambar 3. Profil daya lekat pada penyimpanan suhu dingin, ruang dan tinggi

Daya sebar menggambarkan mudah tidaknya sediaan disebarkan pada permukaan kulit dan keluar dari wadah kemasan. Nilai daya sebar yang semakin tinggi menunjukkan sediaan mudah diaplikasikan pada kulit (Khan et al., 2020). Daya sebar emulgel dan basis menunjukkan rentang 5,2- 5,47 cm. Daya sebar emulgel daging labu kuning (Gambar 4) tidak dipengaruhi oleh ekstrak dan suhu penyimpanan karena perbedaan daya sebar formula tidak berbeda signifikan $(p>0,05)$.
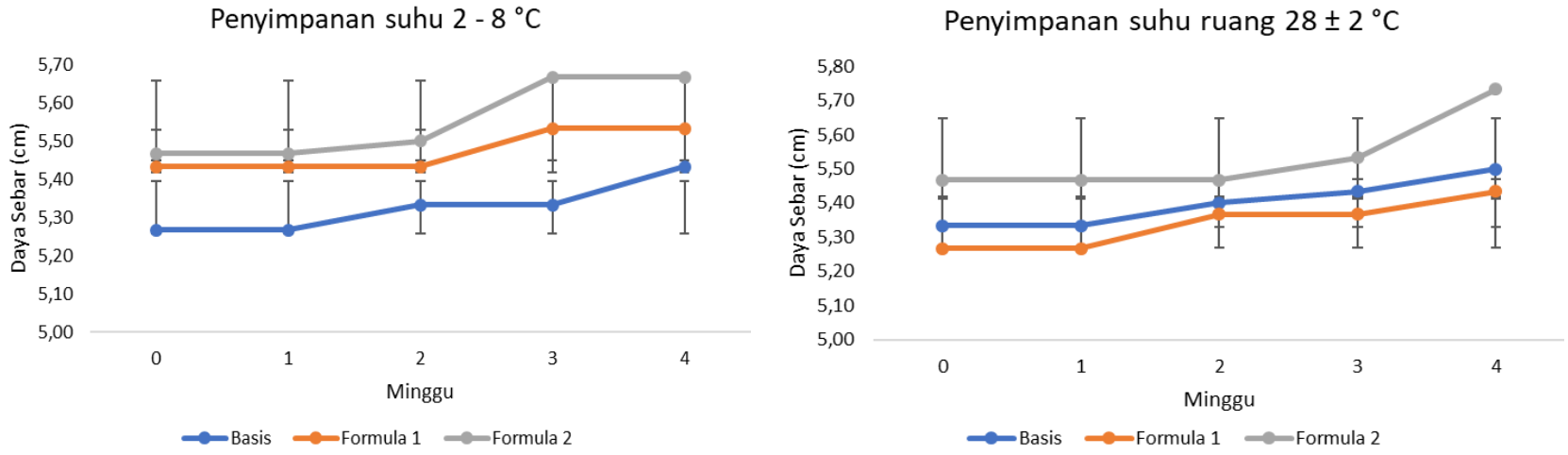


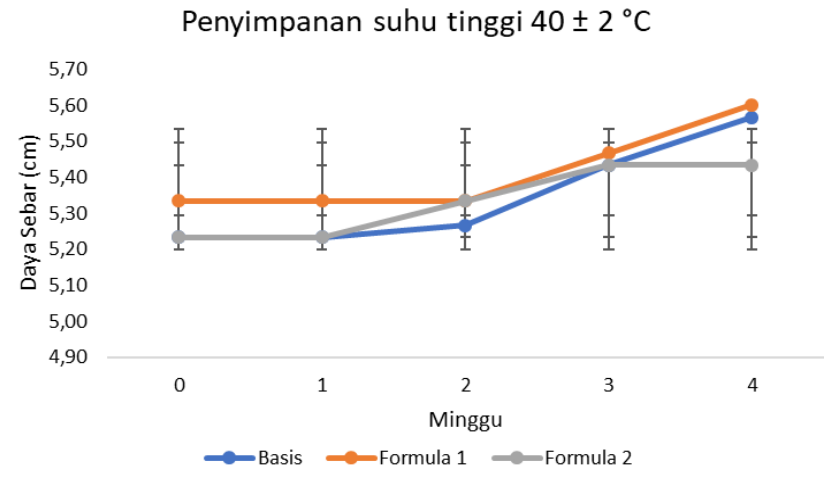

Gambar 4. Profil daya sebar pada penyimpanan suhu dingin, ruang dan tinggi

Penyimpanan suhu $2-8^{\circ} \mathrm{C}$

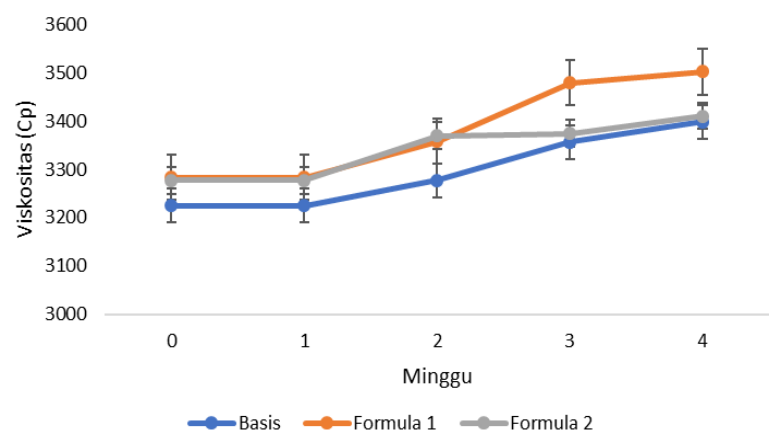

Penyimpanan suhu ruang $28 \pm 2{ }^{\circ} \mathrm{C}$
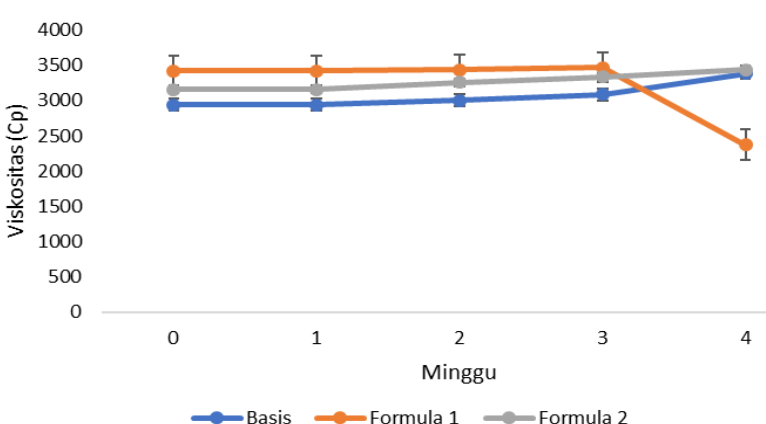

Penyimpanan suhu tinggi $40 \pm 2{ }^{\circ} \mathrm{C}$

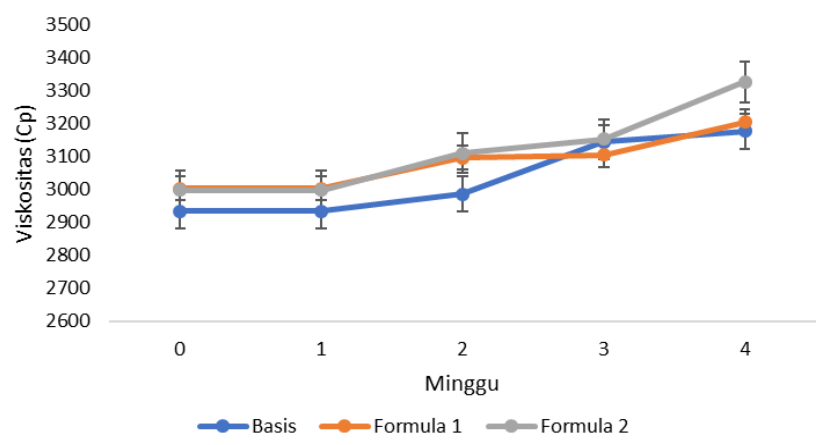

Gambar 5. Profil viskositas pada penyimpanan suhu dingin, ruang dan tinggi

Viskositas merupakan parameter yang penting dievaluasi pada sediaan emulgel. Viskositas menggambarkan konsistensi dari sediaan yang akan menentukan pelepasan bahan aktif (Khan et al., 2020). Viskositas dipengaruhi oleh konsentrasi gelling agent dalam formulasi dengan konsentrasi yang lebih besar akan menaikkan nilai viskositas. Nilai viskositas emulgel dan basis memenuhi persyaratan karena masuk dalam rentang 2000 - 50,000 cP (Eff et al., 2019). Viskositas sediaan emulgel dan basis menunjukkan nilai yang tidak berbeda signifikan $(p>0,05)$ sehingga adanya ekstrak tidak memberikan pengaruh terhadap viskositas (Gambar 5). 
Sediaan emulgel yang dibuat tidak mengalami pemisahan pada uji sentrifugasi pada kecepatan putaran $3800 \mathrm{rpm}$ selama 30 menit sehingga emulgel yang dibuat stabil. Karbomer mampu menjaga stabilitas emulgel ditunjukkan oleh tidak keluarnya cairan dari sistem atau sineresis. Komposisi emulgator yang digunakan pada sistem emulsi juga mampu membentuk sistem emulsi yang stabil sehingga emulgel tidak mengalami perubahan organoleptis serta parameter sifat fisik pH, daya lekat, daya sebar dan viskositas secara signifikan.

\section{Kesimpulan}

Ekstrak daging buah labu kuning mengandung metabolit sekunder flavonoid berdasarkan uji KLT. Formulasi emulgel daging buah labu kuning dan basis yang dilakukan penyimpanan pada suhu $2-8{ }^{\circ} \mathrm{C}$, suhu $28 \pm 2{ }^{\circ} \mathrm{C}$ dan suhu $40 \pm 2{ }^{\circ} \mathrm{C}$ selama 4 minggu menunjukkan karakteristik yang stabil.

\section{Daftar pustaka}

Ambala, R., \& Vemula, S. (2015). Formulation and Characterization of Ketoprofen Emulgels. Journal of Applied Pharmaceutical Science, 5, 112-117. doi:10.7324/JAPS.2015.50717

Baibhav, J., Singh, G., Rana, A. C., \& Seema, S. (2012). Development and Characterization of Clarithromycin Emulgel for topical delivery. International Journal of Drug Development and Research, 4, 310-323.

Eff, A., Rahayu, S., Saraswati, H., \& Mun'im, A. (2019). Formulation and Evaluation of Sunscreen Gels Containing Mangiferin Isolated from Phaleria macrocarpa Fruits. International Journal of Pharmaceutical Investigation, 9, 141-145. doi:10.5530/ijpi.2019.3.26

Erwiyani, A. R., Luhurningtyas), F. P., \& Sunnah, I. (2017). Optimasi Formula Sediaan Krim Ekstrak Etanol Daun Alpukat (Persea Americana Mill ) dan Daun Sirih Hijau (Piper Betle Linn). Cendekia Journal of Pharmacy, 1(1). doi:https://doi.org/10.31596/cjp.v1i1.10

Harborne, J. P. (1996). Metode Fitokimia Penentuan Cara Modern Menganalisis Tumbuhan (2 ed.): Institut Teknologi Bandung.

Indrianingsih, A., Rosyida, V., Apriyana, W., Nur Hayati, S., Nisa, K., Darsih, C., Kusumaningrum, A., Ratih, D., \& Indirayati, N. (2019). Comparisons of Antioxidant Activities of Two Varieties of Pumpkin ( Cucurbita moschata and Cucurbita maxima ) Extracts. IOP Conference Series: Earth and Environmental Science, 251, 012021. doi:10.1088/1755-1315/251/1/012021

Jufri, M., Rachmadiva, G., M, \& Suyono, E. A. (2018). Formulation, Stability Test and In Vitro Penetration Test of Emulgel from Tobacco Leaves Extract. Journal of Young Pharmacists, 10(2), s69-s72. doi:https://doi.org/10.5530/jyp.2018.2s.13

Khan, B. A., Ullah, S., Khan, M. K., Alshahrani, S. M., \& Braga, V. A. (2020). Formulation and Evaluation of Ocimum basilicum-Based Emulgel for Wound Healing Using Animal Model. Saudi Pharm J, 28(12), 1842-1850. doi:10.1016/j.jsps.2020.11.011

Mamahit, T. H., Datu, O., \& Lengkey, Y. K. (2019). Uji Stabilitas Formulasi Sediaan Salep Antibakteri dari Ekstrak Etanol Biji Labu Kuning Cucurbita moschata dengan Variasi Basis. Jurnal Biofarmasetikal Tropis, 2(1), 97-106. Retrieved from https://journal.fmipaukit.ac.id/index.php/jbt/article/view/50 
Muchirah, P. N., Rebecca, W., Shadrack, M., Leila, A., Hastings, O., \& Anselimo, M. (2018). Characterization and Anti-Oxidant Activity of Cucurbita maxima Duchesne Pulp and Seed Extracts. The Journal of Phytopharmacology, 7(2), 134-140.

Mulangsri, D. A. K., \& Zulfa, E. (2020). Uji Aktivitas Antibakteri Ekstrak Terpurifikasi Daun Mangga Arumanis (Mangifera indica L.) dan Identifikasi Flavonoid dengan KLT. Jurnal Farmasi Galenika (Galenika Journal of Pharmacy) (e-Journal) 6(1), 55-62. doi:https://doi.org/10.22487/j24428744.2020.v6.i1.14044

Nakhon, P., Jangchud, K., Jangchud, A., \& Prinyawiwatkul, W. (2017). Comparisons of Physicochemical Properties and Antioxidant Activities among Pumpkin ( Cucurbita moschata L.) Flour and Isolated Starches from Fresh Pumpkin or Flour. International Journal of Food Science \& Technology, 52. doi:10.1111/ijfs.13528

Sari, D., Sugihartini, N., \& Yuwono, T. (2015). Evaluasi Uji Iritasi Dan Uji Sifat Fisik Sediaan Emulgel Minyak Atsiri Bunga Cengkeh (Syzigium Aromaticum). Pharmaciana, 5. doi:10.12928/pharmaciana.v5i2.2493

Shadab, M., \& Shamsi, S. (2020). Original Research Article (Experimental): Design and Development of Unani Emulgel for Vitiligo. Journal of Ayurveda and Integrative Medicine, 11(3), 199-205. doi:https://doi.org/10.1016/j.jaim.2018.01.006

Sunnah, I., Erwiyani, A. R., Melati, N., \& Yunisa, O. (2019). Efektivitas Komposisi Polivynil Alkohol , Propilenglikol dan Karbomer Terhadap Optimasi Masker Gel Peel-off Nano Ekstrak Daging Buah Labu Kuning (Cucurbita maxima D). JPSCR, 4(2), 82-94. doi:https://doi.org/10.20961/jpscr.v4i2.34399

Varma, N. S. K., Maheshwari, P. V., Navya, M., Reddy, S. C., Shivakumar, H. G., \& Gowda, D. V. (2014). Calcipotriol Delivery into the Skin as Emulgel for Effective Permeation. Saudi Pharm J, 22(6), 591-599. doi:10.1016/j.jsps.2014.02.007

Zulkarya, L. G., \& Hastuti, E. D. (2018). Formulasi Sediaan Krim Ekstrak Etanol Rumput Laut Coklat (Padina australis) dan Uji Aktivitas Antioksidan Menggunakan DPPH. Cendekia Journal of Pharmacy, 2(1), 81-87. doi:https://doi.org/10.31596/cjp.v2i1.20 